\title{
Pembinaan Senam Aerobik dalam Upaya Meningkatkan Kebugaran Jasmani Masyarakat Pondok Pinang Lubuk Buaya, Kecamatan Koto Tangah, Kota Padang
}

\author{
Erianti $^{*}$, Pitnawati ${ }^{2}$ \\ 1,2 Program Studi Pendidikan Jasmani Kesehatan dan Rekreasi Fakultas Ilmu Keolahragaan Universitas Negeri Padang
}

\section{A R T I C L E I N F O}

\section{Article history:}

Received 19 August 2018 Received in revised form 19 September 2018 Accepted 20 Oktober 2018 Available online 24

November 2018

\section{Kata Kunci:}

Senam aerobic, kebugaran jasmani

Keywords:

Aerobic exercise, physical fitness

\begin{abstract}
A B S T R A K
Pengabdian Program Penerapan Ipteks bagi masyarakat tentang pembinaan senam aerobik ini dilakukan dalam upaya meningkatkan kebugaran jasmani masyarakat Pondok Pinang Lubuk Buaya Kecamatan Koto Tangah Kota Padang. Berdasarkan pelaksanaan pengabdian yang telah dilaksanakan maka meningkatnya pengetahuan masyarakat tentang kebugaran jasmani dalam kehidupan sehari-hari. Pengetahuan tentang senam aerobik yang dilakukan secara teratur dengan takaran yang cukup akan dapat memperbaiki kerja jantung, dan paru-paru, serta mempunyai banyak manfaat bagi kebugaran tubuh. Meningkatnya pengalaman warga akan keterampilan gerak berirama yang diiringi dengan musik membuat warga dalam melakukan senam aerobik dengan penuh konsentrasi, bersemangat, bergembira dan menikmati indahnya kebersamaan membuat warga yang terlibat ikut kegiatan merasakan manfaatnya. Meningkatnya motivasi dan antusias masyarakat di Perumahan Pondok Pinang Lubuk Buaya Kecamatan Koto Tangah Kota Padang terhadap kegiatan senam
\end{abstract} aerobik. Hal ini dapat dilihat dari kehadiran para peserta senam aerobik di lapangan dan semangat dalam mengikuti serangkaian gerakan yang dipandu dengan irama dan mengikuti instruktur yang menyenangkan. Meningkatnya nilai dan sikap, serta hubungan antar warga masyarakat Perumahan Pondok Pinang Lubuk Buaya Kecamatan Koto Tangah Kota Padang yang mengikuti kegiatan senam aerobik. Hal ini dapat dilihat dari keterampilan gerak berirama yang ditunjukkan warga yang memiliki tingkat kemampuan gerakan yang berbeda-beda.

\section{A B S T R A C T}

Devotional Program Implementation Science for the community about aerobic exercise coaching is done in an effort to improve the physical fitness of Pondok Pinang Lubuk Buaya, Koto Tangah Subdistrict, Padang City community. Based on the implementation of dedication that has been implemented then the increasing knowledge of society about physical fitness in everyday life. Knowledge of aerobic exercise done regularly with adequate doses will improve the work of the heart, and lungs, and has many benefits for fitness. Increased citizens experience of rhythmic motion skills accompanied by music to make residents in doing aerobic exercise with full concentration, passion, fun and enjoy the beauty of togetherness to make the people involved participate in the activities to feel the benefits. Increased motivation and enthusiasm of the community in Pondok Pinang Housing Lubuk Buaya Subdistrict Koto Tangah Padang to aerobic exercise activities. This can be seen from the presence of aerobic exercise participants in the field and the spirit in following a series of movements guided by rhythm and follow the fun instructor. Increasing values and attitudes, as well as relationships among residents Pondok Pinang Lubuk Buaya Community Koto Tangah Subdistrict, Padang City, who participated in aerobic exercise. This can be seen from the skills of rhythmic motion shown by people who have different levels of movement ability.

\footnotetext{
* Corresponding author.

E-mail addresses: erianti@fik.unp.ac.id (Erianti),
} 


\section{Pendahuluan}

Gerakan memasyarakatkan olahraga dan mengolahragakan masyarakat terus ditingkatkan agar lebih meluas dan merata di seluruh pelosok tanah air untuk menciptakan budaya berolahraga dan iklim yang sehat yang mendorong peran serta aktif masyarakat dalam meningkatkan kebugaran jasmani masyarakat, khususnya warga Perumahan Pondok Pinang Kelurahan Lubuk Buaya Kecamatan Koto Tangah Kota Padang. Berdasarkan latar belakang warga Perumahan Pondok Pinang yang pada umumnya memiliki profesi sebagai pekerja kantor seperti dosen, guru dan karyawan/karyawati yang memiliki kesibukan dari pagi sampai sore yang menuntut adanya kebugaran jasmani untuk dapat beraktivitas, maka salah satu aktifitas yang dapat meningkatkan kebugaran jasmani diantaranya dengan berolahaga. Diantara olahraga yang dapat dilakukan warga dan masyarakat untuk menunjang kebugaran jasmani adalah senam aerobik. Pada umumnya usia warga yang berada di Perumahan Pondok Pinang sudah usia 40 tahun ke atas.

Agar dapat melaksanakan seluruh aktivitas kerja yang dikantor maupun aktivitas dirumah, maka para wanita-wanita/ibu harus memiliki kondisi tubuh sehat dan bugar (Astuti, 2017:109). Pertumbuhan seseorang menuju lanjut usia merupakan bagian dari tahap pertumbuhan hidup manusia yang tidak bisa dihindari. Memiliki kebugaran jasmani meski menuju usia semakin lanjut adalah harapan semua orang. Secara umum, yang dimaksud kebugaran adalah kebugaran fisik (physical fitness), yakni kemampuan tubuh untuk menyesuaikan fungsi alat-alat tubuh dalam batas fisiologi terhadap keadaan lingkungan atau kerja fisik secara efisien tanpa kelelahan yang berlebihan. (Mutohir dkk, 2004:117). Pada saat memasuki usia lanjut, fungsi-fungsi tubuh tidak dapat lagi berfungsi dengan baik, maka lansia membutuhkan banyak bantuan dalam menjalani aktivitas-aktivitas kehidupannya. Belum lagi berbagai penyakit yang menyertai keadaan lansia yang membuat mereka memerlukan perhatian ekstra dari orang-orang di sekelilingnya. Aktivitas olahraga akan membantu tubuh tetap bugar dan segar karena melatih tulang tetap kuat, mendorong jantung bekerja optimal, dan membantu menghilangkan radikal bebas yang berkeliaran di dalam tubuh, dengan kata lain mempunyai kebugaran jasmani yang baik bila jantung dan peredaran darah baik sehingga seluruh tubuh dapat menjalankan fungsinya dalam waktu yang cukup lama. Berkaitan dengan kebugaran jasmani yang dikatakan sebagai kemampuan yang dimiliki untuk tetap bisa melakukan aktivitas tanpa mengalami kelelahan yang berarti, kebugaran jasmani pada seseorang memiliki fungsi yang berperan sebagai penunjang kualitas aktivitas yang dilakukan. Hal ini sesuai dengan fungsinya kebugaran jasmani menurut menurut Ismaryati (2006:40) dikelompokan menjadi dua yaitu umum dan khusus. Fungsi umum adalah untuk mengembangkan kekuatan, kemampuan, kesanggupan, daya kreasi dan daya tahan setiap manusia untuk mempertinggi daya kerja. Fungsi khusus adalah sesuai kekhususan masing- masing sesuai pekerjaan (misalnya: atlet, pelajar, pekerja kantoran), keadaan (misalnya: ibu hamil) dan umur (misalnya: bagi anak untuk merangsang pertumbuhan dan bagi lansia untuk mempertinggi ketahanan tubuh).

Pentingnya kebugaran jasmani yang baik untuk menunjang aktivitas kerja terutama masyarakat yang sudah memasuki usia lanjut untuk mempertahankan dan meningkatkan kebugaran jasmani tersebut dapat dilakukan dengan cara melakukan senam aerobik. Melaksanakan senam aerobik akan meningkatkan efisien paru-paru dan kerja jantung, aktivitas bermanfaat untuk meningkatkan dan mempertahankan katahanan kardiorespiratori. Penulis akan melakukan pengabdian kepada masyarakat dengan melakukan pembinaan senam aerobik dalam upaya meningkatkan kebugaran jasmani masyarakat Pondok Pinang Lubuk Buaya Kecamatan Koto Tangah Kota Padang.

Kebugaran jasmani menurut Sutarman dalam Mutohir dkk (2004:117) adalah merupakan kondisi individu dari kebugaran menyeluruh (total fittness) yang memberikan kasanggupan kepada seseorang untuk menjalankan hidup yang produktif dan dapat menyesuaikan pada tiap pembebanan atau stress fisik yang layak". Sedangkan Sri Wahyu Ningsih Nugraheni (2013:34) mengatakan "Kebugaran jasmani adalah:

Merupakan salah satu tolak ukur kesehatan masyarakat setiap kelompok masyarakat termasuk lansia. Lansia yang memiliki kebugaran jasmani yang tinggi selain sehat dan segar juga dapat melakukan aktivitas sehari hari secara mandiri. Kebugaran jasmani yang buruk pada lansia sering membuat lansia terlihat tidak sehat dan sering mengalami cedera akibat terjatuh. Proses menua tidak dapat dihindari oleh semua orang. Proses penuaan sering disertai oleh adanya peningkatan gangguan organ dan fungsi tubuh, terjadi perubahan komposisi tubuh, terjadi penurunan massa bebas lemak dan peningkatan massa lemak. Pada proses penuaan ini prosentase massa otot menurun. Kekuatan otot pada lansia juga berhubungan dengan masalah terjadinya keseimbangan yang mempunyai resiko lansia mudah terjatuh".

Menurut Astuti (2017:147) mengatakan bahwa "kebugaran jasmani merupakan kemampuan yang dimiliki untuk tetap bisa melakukan aktivitas tanpa mengalami kelelahan yang berarti, kebugaran jasmani pada seseorang memiliki fungsi yang berperan sebagai penunjang kualitas aktivitas yang dilakukan". Berdasarkan pendapat dari kutipan yang diuraikan tersebut, maka jelaslah bahwa kebugaran adalah 
serangkaian karakteristik fisik yang dimiliki atau dicapai seseorang yang berkaitan dengan kemampuan untuk melakukan aktivitas fisik. Adapun seseorang yang bugar diartikan sebagai orang yang mampu menjalankan kehidupan sehari-hari tanpa melampaui batas daya tahan stres pada tubuh dan memiliki tubuh yang sehat serta tidak berisiko mengalami penyakit yang disebabkan rendahnya kebugaran jasmani atau kurangnya aktivitas fisik. Ada sejumlah komponen diberikan untuk mencapai kebiasaan kerja. Ada orang memelihara kesegaran jasmani refleksi dengan kardiorespiratori: yang lain termasuk kelentukan, kelincahan, kecepatan, keseimbangan dan koordinasi.

Faktor lain yang mempengahi kesegaran jasmani adalah gaya hidup, baik pada usia sebelum pensiun dan sekarang seperti kebiasaan merokok, mengkonsumsi makanan berlemak dan jarang melakukan olah raga (Yuniar Rosmalina dkk, 2003:11). Selanjutnya komponen dari kesegaran jasmani yang berhubungan dengan kesehatan menurut Depdiknas (2000:53) yaitu "1) Daya tahan jantung. 2) Daya tahan otot. 3) Kekuatan otot. 4) Tenaga ledak otot. 5) Kelentukan. Sedangan yang berhubungan dengan keterampilan yaitu 1) Keseimbangan. 2) Ketangkasan. 3) Keseimbangan. 4) Kecepatan reaksi. 5) Koordinasi. 6) Komposisi tubuh".

Berpedoman dari dua pendapat di atas, maka jelaslah bahwa banyak sekali komponen-komponen kesegaran jasmani. Berikut akan dijelaskan beberapa komponen kesegaran jasmani yang dapat dimiliki seseorang dengan melakukan aktiftas senam aerobik yakni sebagai berikut:

1. Daya tahan jantung dan daya tahan otot

Daya tahan jantung merupakan factor utama alam kesegaran jasmani, dan sering disebut dengan daya tahan kardiorespirasi, kapasitas aerobic, maxsimal aerobik power dan sebagainya. Daya taham jantung dan paru menurut Depdiknas (2000:53) adala "kemampuan untuk terus menerus engan tetap menjalani kerja fisik yang mencakup sejumlah besar otot dalam waktu tertentu, hal ini merupakan kemampuan system peredaran darah, dan system pernafasan untuk menyesuaikan diri terhadap efek seluruh beban kerja fisik".

Daya tahan kardiofaskuler dihubungkan pada kerja atau kontraksi melebihi periode waktu. Penekanan ditempatkan pada paru, pernafasan dan system sirkulasi dari tubuh sewaktu ia harus disuplay cukup oksigen pada otot, sudah pastipenyusuaian dibuat pada system ini selama menggunakan permintaan prinsip overloadingnya. Sedangkan yang dimaksud dengan daya tahan otot menurut beberapa para ahli merupakan kemampuan daya tahan otot untuk menjalani kontraksi dengan beban submaksimal secara berulang-ulang aau mempertahankan kontraksi otot dalam priode waktu tertentu . Hal ini merupakan kapasitas otot dalam melakukan kerja aerobic secara terus menerus.

2. Kekuatan otot

Komponen yang paling mendasar untuk sukses dalam semua gerak adalah kekuatan, kekuatan otot didefenisikan sebagai suatu bagian oleh tenaga yang dapat digunakan oleh otot. Syafruddin (2011:94) adalah "merupakan kemampuan untuk menggerakan sebuah masa (tubuh sendiri, lawan, alat) dan juga untuk mengatasi suatu beban melebihi kerja otot". Banyak tingkat kekuatan yang digunakan oleh otot tergantung pada tipe kerja atau kegiatan yang dikejakan melebihi keinginan setiap hari. Secara fhysiologis, otot akan meningkat dalam kekuatannya jika ia diberikan peningkatan kerja melebihi beban, apakah pemakai suatu bebanan biasa, tidak meningkat jika tidak ditambah usaha atau intensitas latihan dan kegiatan.

3. Kelincahan

Kelincahan adalah kemampuan dari seseorang untuk merubah arah atau posisi tubuh dengan cepat dan mendapatkan kembali istirahat atau mengontrol untuk hasil dengan gerakan lain. Ismaryati (2006:41) mengatakan kelincahan merupakan komponen kesegaran jasmani yang sangat diperlukan pada semua aktifitas yang membutuhkan kecepatan perubahan posisi tubuh dan bagian-bagiannya". Kelincahan yang tinggi tergantung pada hubungan dengan kecepatan, kekuatan, keseimbangan dan koordinasi ini dikembangkan melalui latihan dan kepercayaan dalam gerak. Pengajaran dan kesempatan berpartisipasi dalam kegiatan memerlukan kecepatan star, berhenti dan merobah gerakan lari arah akan termasuk program latihan olahraga.

4. Kelentukan

Kelentukan menurut Bafirman (2013:128) adalah „kemampuan tubuh untuk menggunakan otot dan persendian dengan rntang yang luas, kelentukan dinams dan kelentukan statis“. Tingkat dari kelentukan menentukan luas dari keluasan dalam suatu hubungan dan konsekuensi tubuh dalam istilah ketul/ tekuk, meraih, memutar dan memilin. Tingkat dari kelentukan adalah terutama ditentukan oleh kebiasaan dari tulangnya sendiri dan kemudian oleh ligament dan hubungan otot pada tulang. Kelentukan sangat spesifik untuk setiap tulang, mungkin agak lentur untuk suatu bagian tetapi tidak bagi yang lain. Suatu tingkat tinggi dari kelentukan tidak hanya dapat oleh seseorang untuk melakukan berapa latihan yang lebih efisien tapi juga keselamatan factor dalam istilah menahan tiba-tiba atau pukulan sekitar 
tulang yang mudah kena serang terutama pada tulang lutut yang mudah mendapatkan kecelakaan pada tekanan tiba-tiba pada kegiatan sehari-hari.

\section{Power/ Tenaga}

Tenaga adalah kemampuan dari tubuh untuk pembebasan tenaga maksimal atau kontraksi otot dalam waktu sesingkat mungkin. Power menunjukkan gerakan explosif, suatu pembebasan dari tenaga maksimum. Dengan nyata tinggi power tergantung pada elemen kecepatan dan kekuatan. Power adalah komponen penting untuk behasil dalam penampilan melompat,menyepak star untuk berlari dengan suatu kecepatan tumpuan atau ledakan tiba-tiba dari kecepatan atau tarikan keluar menjauh dari suatu keheningan. Ia dapat dikembangkan melalui pemberian kekuatan dan latihan dari kegiatan yang tepat.

6. Kecepatan

Kecepatan adalah kemampuan seseorang dalam berpindah tempat dari suatu titik ke titik lainnya Dalam waktu yang sesingkat singkatnya. Kecepatan yang besar dalam kontraksi otot adalah tidak selalu menghasilkan efisiesi otot adalah tidak selalu menghasilkan efisiensi yang paling besar dari gerakan. Sukses dalam suatu kegiatan yang lebih tinggi tergantung pada bagaimana cepatnya seseorang dapat mengerjakan bagian tubuhatau semua tubuh dari suatu tempat ke tempat yang lain. Hal ini diperkuat oleh pendapat yang dikemukakan oleh Syafruddin (2011:122) kecepatan adalah "kemampuan seseorang ntuk menyelesaikan suatu jarak tertentu dengan cepat".

\section{Keseimbangan}

Keseimbangan menurut Depdiknas (2000:57) adalah "kemampuan untuk mempertahankan sikap tubuh yang tepat pada saat melakukan gerakan, keseimbangan tidak hanya diperlukan pada olahraga akan tetapi juga diperlukan dalam kehidupan sehari-hari. Sesuai dengan pendapat ini jelaslah bahwa setiap manusi membutuhkan keseimbangan yang baik, sehingga semua aktivitas sehari-hari karena suatu posisi yang di inginkan dari tubuh apakah dalam suatu statik atau mempertahankan posisi dalam suatu bagian dinamis atau bergerak. Ini menunjukkan suatu tingkat dari kestabilan dan meringankan dalam mengontrol tubuh dalam suatu posisi spesifik.

8. Koordinasi

Koordinasi adalah kemampuan untuk mengintegrasikan gerakan otot ke dalam suatu pola gerak yang efisien. Koordinasi membuat perbedaan antara penampilan yang baik dan yang kurang baik. Pola keefisiensian dari keterampilan tergantung pada interelasi dari kecepatan, kelincahan, keseimbangan dan gerakan otot pada suatu pola koordinasi dengan baik. Koordinasi yang baik tidak hanya penting dalam performan yang baik dalam berolahraga dan keterampilan dalam permainan, tapi juga vital untuk seharihari dan tugas kujujuran dimana gerakan efisien dan perlindungan dari energi adalah penting.

Fungsi kebugaran dalam aktivitas kehiduapan sehari-hari didukung oleh kardio-respirasi yang baik, kekuatan otot, ketahanan otot, kelenturan otot dan komposisi badan seimbang. Selain itu aktiviatas kehidupan sehari-hari didukung oleh status mental yang normal tidak terjadi perubahan patologis yang signifikan dalam otak pada lansia berupa dimensia. Usia lanjut dikatakan sebagai tahap akhir perkembangan pada daur kehidupan manusia.

Berdasarkan defenisi secara umum, seseorang dikatakan lanjut usia (lansia) Menurut Depkes RI (2009) usia yang termasuk lansia itu terdapat 2 kategori yaitu masa lansia awal usia 46 - 55 Tahun dan masa usia akhir yaitu usia 56 Tahun ke atas. Lansia bukan suatu penyakit, namun merupakan tahap lanjut dari suatu proses kehidupan yang ditandai dengan penurunan kemampuan tubuh untuk beradaptasi dengan stres lingkungan. Lansia adalah keadaan yang ditandai oleh kegagalan seseorang untuk mempertahankan keseimbangan terhadap kondisi stres fisiologis. Kegagalan ini berkaitan dengan penurunan daya kemampuan untuk hidup serta peningkatan kepekaan secara individual.

Proses penuaan pada manusia merupakan proses yang alami, hal ini ditandai dengan adanya penurunan kondisi tubuh, baik fisik, maupun psikis pada lansia. Oleh karena itu, para lansia perlu menjaga kondisi tubuhnya, salah satunya dengan melakukan senam lansia. Lansia memiliki karakteristik sebagai berikut: berusia lebih dari 46 tahun, kebutuhan dan masalah yang bervariasi dari rentang sehat sampai sakit, dari kebutuhan biopsikososial sampai spiritual, serta dari kondisi adaptif hingga kondisi maladaptif, lingkungan tempat tinggal bervariasi. Menurut Irhas Azizin (2014:18) apabila "semakin tinggi derajat kebugaran jasmani seseorang, semakin besar kemampuan fisik dan produktivitas kerjanya"

Tarian aerobik populer pada akhir 1970-an. Namun, saat ini senam aerobik digemari berbagai kalangan usia. Hal tersebut dapat dilihat setiap Minggu pagi, lapangan-lapangan atau di pelataran parkir dijadikan sebagai tempat untuk melakukan senam aerobic. Iwan Kristono dalam Joni (2003:3) mengatakan aerobic yaitu "latihan yang bertujuan untuk meningkatkan kemampuan paru-paru, jantung, serta peredaran darah, dimana oksigen merupakan factor utama pembangkit energy pada sel-sel tubuh". Sementara yang dimaksud dengan senam aerobic menurut Pitnawati (2013:9) adalah "olahraga yang mudah dilakukan karena mengikuti gerak instruktur dan mengikuti irama lagu. Gerakan senam dapat digunakan sedemikian rupa sehingga seluruh otot badan atau tubuh ikut bergerak, kemudian dapat 
menambah motivasi dan menyenangkan karena music/lagu-lagu yang dipilih disesuaikan dengan selera pesenam".

Sesuai dengan dua pendapat di atas, maka dapat diambil suatu kesimpulan bahwa senam aerobik adalah serangkaian gerak yang dipadukan dengan irama musik yang telah dipilih dengan durasi tertentu dengan mengikuti gerak instruktur yang menyenangkan karena diiringi oleh music sesuai dengan selera peserta senam aerobic. Aerobik mengandung pengertian suatu sistem latihan fisik yang bertujuan untuk meningkatkan efisiensi pemasukan oksigen di dalam jaringan tubuh. Pemasukan oksigen ini ditentukan oleh kapasitas maksimal paru-paru saat menghirup udara.

Selanjutnya senam aerobik yang dilakukan secara teratur dengan takaran yang cukup akan memperbaiki kerja jantung dan paru-paru, dan mempunyai banyak manfaat bagi kebugaran tubuh, dan tidak heran semakin hari semakin banyak orang yang menggemari dan melakukan senam aerobik. Sharkey (2003:74) mengatakan bahwa "kebugaran aerobic adalah kapasitas maksimal untuk menghirup, menyalurkan dan menggunakan oksigen". Kebugaran aerobic ini dapat diperoleh diantaranya dengan melakukan senam aerobic dan manfaatnya akan dapat dirasakan bagi yang melakukan dengan teratur dan dengan cara yang benar.Berikut ini merupakan manfaat melakukan senam aerobik.

a. Meningkatkan Daya Tahan Jantung dan Paru-Paru

Selama bergerak, otot membutuhkan asupan oksigen untuk bekerja. Ketika beban kerja meningkat, tubuh menanggapinya dengan meningkatkan jumlah oksigen yang dikirim ke seluruh otot dan jantung. Akibatnya, detak jantung dan frekuensi pernapasan meningkat sampai memenuhi kebutuhannya. Oksigen diubah menjadi karbondioksida, yang kemudian diembuskan. Selain itu, tubuh akan berkeringat membakar kalori dan lemak.

b. Meningkatkan Kekuatan Otot

Otot-otot harus dilatih melebihi beban normal. Hal ini disebut prinsip beban lebih (overload system). Untuk meningkatkan kekuatan otot, harus dilatih pada intensitas yang tinggi dalam waktu singkat, mempergunakan tenaga yang maksimal dan dilakukan secara diulang-ulang. Selain itu, berikan beban yang bervariasi supaya lebih, karena intensitas latihan beragam, dari latihan berintensitas tinggi sampai dengan intensitas yang sangat rendah, sebagai contoh aktivitas bersepeda.

c. Meningkatkan Kelentukan

Kelentukan adalah gerakan yang berada di sekeliling sendi. Setelah menyelesaikan latihan aerobik, melakukan peregangan akan membantu meningkatkan kelentukan dan juga membantu sirkulasi darah ke jantung. Otot sifatnya seperti pita karet. Semakin kuat mengangkatnya, semakin elastis karet itu. Jika secara rutin meregangkan badan selesai latihan, akan membuat otot persendian akan berkembang.

d. Komposisi Tubuh

Latihan aerobik yang tepat akan membantu mengubah komposisi tubuh, menghindari tubuh menjadi gemuk dan membentuk otot-otot. Hal terpenting yang harus diingat adalah bahwa aerobik tidak dapat mengurangi berat badan hanya pada satu bagian tubuh saja. Aturan dalam melakukan latihan senam aerobik adalah sebagai berikut.

a. Pemanasan

Pemanasan (warming up) adalah persiapan emosional, psikologis, dan fisik untuk melakukan latihan. Tujuan latihan pemanasan adalah menaikkan denyut jantung secara berangsur-angsur, mempersiapkan otot-otot dan persendian, meningkatkan suhu inti tubuh, meningkatkan sirkulasi cairan tubuh, dan mempersiapkan diri secara psikologis dan emosional.

b. Gerakan Inti Aerobik

Gerakan inti merupakan gerakan yang telah aktif dengan mengikuti alur tertentu. Gerakan inti bertujuan untuk menguatkan otot-otot tubuh dan melatih koordinasi gerak antar anggota tubuh.

c. Gerakan Pendinginan

Gerakan pendinginan bertujuan untuk mengembalikan frekuensi denyut jantung supaya kembali mendekati normal. Pelaksanaan gerakan dilakukan secara bertahap dari intensitas tinggi ke intensitas yang rendah. Dalam melakukan senam aerobik selalu diiringi musik. Irama musik dalam aerobik berfungsi sebagai panduan gerak, pemberi motivasi, dan semangat peserta yang melakukan senam aerobik. Oleh karena itu, pilihlah irama musik aerobik yang menyenangkan, penuh energi, dan mempunyai warna yang menggerakkan. Musik yang dipilih biasanya mempunyai empat ketukan per irama dengan irama yang tetap. Menurut cara melakukan dan musik yang mengiringinya, senam aerobik dapat dibagi sebagai berikut : 1) Low impact aerobic, yaitu senam aerobik gerakan ringan, 2) Higt impact aerobic, yaitu senam aerobik gerakan keras, 3) Discorobic, yaitu kombinasi antara gerakan ringan dan keras, 4) Rockrobic, yaitu kombinasi antara gerakan ringan dan keras, 5) Aerobic sport, yaitu kombinasi antara gerakan aerobik keras dan ringan, 6) Aerobic dance, yaitu senam aerobik yang dilakukan dengan kombinasi bentuk tarian yang indah, 7) Aerobik dengan menggunakan alat, pada dasarnya adalah upaya menambah 
variasi, intensitas, serta volume latihan agar lebih meningkat. Biasanya, menggunakan peralatan, antara lain kursi, bangku, tali (pita), tongkat, dan bola.

Tips untuk olahraga aerobik yang baik yaitu berlatih 3 - 5 kali seminggu, Durasi disarankan antara 20 sampai 30 menit dan tingkat intensitas 50-80\% dari maksimum kemampuan masing-masing, apapun jenis aerobik yang diplih pertama-tama harus menyediakan waktu untuk pemanasan 5 sampai 10 menit, kemudian setelah berlatih sediakan waktu juga 5 sampai 10 menit untuk peregangan, untuk mencegah kemungkinan cedera dan jika memulai program latihan, mulailah secara perlahan dan secara bertahap meningkatkan intensitas dan durasi. Hal ini dapat mengambil waktu beberapa minggu hingga anda dapat berlatih secara konstan 20 sampai 30 menit.

Hal ini dikuatkan oleh penelitian sebelumnya yang dilakukan oleh Fathirina Sientia (2012) yang menyatakan bahwa, terdapat perbedaan bermakna rerata penurunan berat badan $(p=0,022)$ pada peserta senam aerobik dengan tingkat aktivitas fisik yang berbeda dan asupan makan tidak berpengaruh $(\mathrm{p}=$ 0,427 ) terhadap berat badan peserta setelah mengikuti latihan senam aerobik selama 12 minggu di klub kebugaran. Purwanto (2011) juga menyatakan bahwa Berdasarkan temuan penelitiannya dapat disimpulkan bahwa senam aerobik dapat berdampak pada daya tahan tubuh terhadap penyakit. Hal senada juga diungkapkan oleh Azmy Andini (2016) yang menyatakan bahwa frekuensi senam aerobik $\geq 3$ kali dalam semingga dapat menurunkan persentase lemak tubuh dan berat badan lebih tinggi daripada frekuensi senam aerobik $\leq 2$ kali dalam seminggu, Jeane Betty, K J (2013) menyatakan terdapat pengaruh latihan senam aerobik terhadap tingkat kebugaran jasmani siswa putri kelas VII SMP Kartika XII-I Mertoyudan Magelang. Hal senada juga diungkapkan oleh Nanik Sugiarti (2009) yang menyatakan bahwa Rata-rata penurunan berat badan kelompok program umum sebesar 0,34 kg dan program khusus sebesar $1,32 \mathrm{~kg}$ dengan nilai $\mathrm{p} 0,055$. Lama latihan pada program olahraga umum (senam aerobik) memberikan pengaruh yang signifikan terhadap penurunan berat badan dengan nilai p 0,007, sedangkan intensitas dan keteraturan latihan tidak memberikan pengaruh yang signifikan.

\section{Metode}

Dalam menyampaikan materi kepada para peserta akan dipakai beberapa macam metode dan penggunaan media yang relevan antara lain dengan metode ceramah, diskusi, peragaan atau demonstrasi dan pelatihan sesuai dengan topik-topik yang diberikan. Sebagaimana yang telah dikemukakan dalam uraian terdahulu bahwa berbagai permasalahan-permasalahan yang ditemui di lapangan sehubungan dengan belum adanya optimalisasi peran perangkat Rukun Warga dalam upaya peningkatan kebugaran jasmani. Dalam hal ini upaya yang dilakukan adalah dengan memberikan pengertian dan pemahaman pentingnya kebugaran jasmani, dan untuk mencapainya kebugaran jasmani tersebut dapat dilakukan dengan senam aerobik. Untuk itulah perlu kiranya dilakukan pembinaan senam aerobik kepada khalayak sasaran strategis dengan memberikan sejumlah materi yang relevan sesuai dengan masalah yang ada. Dalam kegiatan ini yang menjadi khalayak sasaran antara yang strategis adalah pelatih (instruktur), dan masyarakat yang berada di Perumahan Pondok Pinang Kelurahan Lubuk Buaya Kecamatan Koto Tangah Kota Padang, melalui kerjasama dengan bapak RW IX dan Lurah Lubuk Buaya Kecamatan Koto Tangah Kota Padang. Sebagai institusi pelaksanaan adalah Universitas Negeri Padang melalui Lembaga Pengabdian Kepada Masyarakat. Dalam pelaksanaan nantinya memerlukan kerjasama dengan berbagai instansi antara lain dengan Pemerintah Kota Padang dalam hal ini adalah Lurah Lubuk Buaya Kecamatan Koto Tangah Kota Padang. Dalam menyampaikan menyampaikan materi pada para peserta senam aerobik dipakai beberapa metode dan penggunakan media yang relevan antara lain adalah metode ceramah, demontrasi, peragaan, diskusi sesuai dengan topik-topik yang diberikan.

\section{Hasil dan pembahasan}

Berdasarkan pelaksanaan penerapan IPTEKS yang berjudul "Pembinaan senam aerobik dalam upaya meningkatkan kebugaran jasmani masyarakat Pondok Pinang Lubuk Buaya Kecamatan Koto Tangah Kota Padang", maka hasil yang dicapai dideskripsikan sebagai berikut:

Meningkatnya pengetahuan masyarakat di Perumahan Pondok Pinang Lubuk Buaya Kecamatan Koto Tangah Kota Padang tentang kebugaran jasmani dalam kehidupan sehari-hari. Pengetahuan tentang senam aerobik yang dilakukan secara teratur dengan takaran yang cukup akan dapat memperbaiki kerja jantung, dan paru-paru, serta mempunyai banyak manfaat bagi kebugaran tubuh.

Pengetahuan kebugaran jasmani merupakan hal yang sangat penting untuk dipahami dan dimengerti oleh masyarakat, khususnya di Perumahan Pondok Pinang Lubuk Buaya Kecamatan Koto Tangah Kota Padang. Kebugaran jasmani yang yang dimiliki seseorang dengan baik tentu akan mempengaruhi kemampuan atau kesanggupan dalam menyelesaikan tugas sehari-hari yang banyak 
menuntut kebugaran fisik dan dikaitkan dengan kesehatan yang lebih baik. Aerobik yang dilakukan bertujuan "untuk meningkatkan kemampuan paru-paru, jantung serta peredaran darah, dimana oksigen merupakan faktor utama pembangkit energi pada sel-sel tubuh (Joni, 2003:3)". Aerobik dapat juga dikatakan adalah olahraga kesehatan yang meliputi segala latihan menggunakan aksigen dengan menggerakkan otot-otot besar secara ritmis, dinamis, cukup lama tanpa berhenti, cukup intensif dan tercapainya perubahan yang menguntungkan bagi tubuh. Selanjutnya pengetahuan masyarakat bertambah dan menjadi lebih baik pandangnya terhadap manfaat dari senam aerobik yang mereka lakukan dalam mengatasi bebarapa permasalahan dalam menjalankan aktivitas sehari-hari. Diantaranya memiliki pengetahuan dalam menjalan aktivitas yang melibatkan fisik, dengan melakukan senam aerobik dapat membantu mengubah komposisi tubuh, menghindari tubuh menjadi gemuk dan membentuk otototot menjadi lebih kuat, daya tahan dan kekuatan tubuh meningkat, kelentukan menjadi baik, dan badan terasa ringan dan segar sehingga kegiatan yang dilakukan menjadi mudah.

Meningkatnya pengalaman warga akan keterampilan gerak berirama yang diiringi dengan musik membuat warga dalam melakukan senam earobik dengan penuh konsentrasi, bersemengat, bergembira dan menikmati indahnya kebersamaan membuat warga yang terlibat ikut kegiatan merasakan manfaatnya.

Pembinaan senam aerobik yang dilakukan masyarakat di Perumahan Pondok Pinang Lubuk Buaya Kecamatan Koto Tangah Kota Padang dapat meningkatkan keterampilan gerakan. Keterampilan gerakan yang disajikan pada peserta senam aerobik di Perumahan Pondok Pinang Lubuk Buaya Kecamatan Koto Tangah Kota Padang meliputi berbagai gerak dalam a (1) melakukan pemanasan (warming-up) selama 58 menit atau 10-15 menit. (2) Melakukan gerakan peregangan, karena dalam senam aerobik membutuhkan kelenturan yang baik dan dapat dicapai dengan latihan peregangan. (3) Melakukan latihan senam aerobik dengan mengikuti rangkaian gerakan yang diiringi dengan musik dan dipandu oleh instruktur. Dengan demikian dapat dijelaskan bahwa dari berbagai gerakan disajikan dalam bentuk rangkai gerakan yang diiringi dengan musik, sudah ditata sedemikian rupa, dan yang pasti melibatkan aktifitas fisik dengan waktu relatif lama. Jenis musik yang dipakai untuk kegiatan senam aerobik adalah jenis musik pop dan dangdut yang sangat populer di Indonesia. Musik pop, biasanya alunan musik/refren yang mudah diingat dan mempunyai daya tarik bagi peserta senam aerobik. Sedangkan musik dangdut mempunyai ciri-ciri tempo musik yang dapat membikin orang untuk bergoyang atau lebih banyak bergerak.

Gerakan pemanasan dimaksud dilakukan dengan gerak banyak ditempat, kemudian diutamakan gerakan yang bersifat kalistenik karena hal ini baik untuk meregangkan otot, dengan ketentuan gerak kalistenik sebagai tambahan. Kemudian gerakan peregangan ditampilan yang sifatnya untuk menggurangi ketegangan otot, membantu koordinasi gerakan tubuh, mencegah cidera atau kecelakaan dalam melakukan latihan senam aerobik, dapat membuat aktifitas latihan yang berat menjadi ringan, dan dapat memperlancar sirkulasi darah, serta membantu pengenduran saraf otak. Keterampilan gerakan senam aerobik yang diberikan oleh instruktur sangat bervariasi dan dikembangkan dalam hal ; (1) Rangkaian gerakan tangan lebih dikembangkan dan bervariasi untuk mencapai intensitas latihan atau melatih otototot tertentu. Koreografikan rangkaian gerakan tangan dengan lebih kreaktif dapat diterapkan secara sistematis dan mendemontrasikan gerakan yang dilakukan oleh instruktur. (2) Pola ruang yang berpindah, maksudnya menggunakan pola yang lebih variaktif dengan pola bentuk berpindah ke depan, kesamping kanan dan ke samping kiri, mundur ke belakang dan berputar.

Rangkaian gerakan latihan yang diberikan akan dapat meningkatkan pengayaan keterampilan gerakan secara bervariasi dengan berputar dengan empat arah yaitu muka, belakang, samping kanan dan samping kitri. Variasi yang dimaksud dalam hal ini adalah menggunakan gerakan yang mudah diserap oleh peserta senam aerobik dan mampu mengikuti variasi-variasi gerakan yang dilakukan oleh instruktur yang berada di depan para peserta senam aerobik di Perumahan Pondok Pinang Lubuk Buaya Kecamatan Koto Tangah Kota Padang. Kemudian instruktur senam aerobik pada saat latihan juga memberikan keterampilan gerak variasi langkah kaki pada peserta latihan senam aerobik dengan berbagai gerakan seperti melakukan berjalan ke depan atau kebelakang, ke samping kiri dan ke samping kanan, serta berputar sambil menhentak-hentakan kaki dengan irama musik yang mengairahkan sambil para peserta mengikuti dengan penuh semangat dengan mengikuti nyanyian. Hal ini dilakukan dengan tujuan agar peserta senam aerobik tidak merasa bosan untuk mengikuti gerakan-gerakan yang diterapkan instruktur.

Selanjutnya peserta senam aerobik juga memperoleh keterampilan gerak dengan tujuan untuk penenangan, atau yang lebih dikenal dengan pendinginan (cooling down) selama 5-8 menit dan kadangkadang dilakukan selama 10-15 menit. Pendingin ini dilakukan dengan gerakan yang bersifat kalistemik agar dapat menurunkan suhu tubuh kepada kondisi semula. Pendinginan (cooling down) dapat diartikan yaitu melakukan gerakan-gerakan ringan untuk beberapa saat setelah melakukan kegiatan latihan gerakan inti yang berat dan pendinginan bagian yang tidak boleh dilupakan dari latihan-latihan senam 
aerobik yang dilakukan. Dari hasil penelitian pendinginan (cooling down) sangat bermanfaat bagi otot, ligamen dan tendo, serta dapat menurunkan secara bertahap kecepatan denyut jantung menjadi seperti waktu istirahat.

Meningkatnya motivasi dan antusias masyarakat di Perumahan Pondok Pinang Lubuk Buaya Kecamatan Koto Tangah Kota Padang terhadap kegiatan senam aerobik. Hal ini dapat dilihat dari kehadiran para peserta senam aerobik di lapangan dan semangat dalam mengikuti serangkaian gerakan yang dipandu dengan irama dan mengikuti instruktur yang menyenangkan.

Masyarakat di Perumahan Pondok Pinang Lubuk Buaya Kecamatan Koto Tangah Kota Padang meningkat motivasinya terhadap senam aerobik meningkat, hal ini dapat dilihat dari kehadiran, semangat, ketekunan dan konsentrasi para peserta senam aerobik dalam mengikuti setiap gerakan senam aerobik yang diberikan instruktur dengan berbagai-bagai variasi latihan mulai dari awal pemanasan, latihan inti dan latihan pendinginan atau sampai berakhirnya latihan. Motivasi merupakan dorong yang muncul dalam diri individu untuk melakukan sesuatu kegiatan dengan tujuan tertentu. Motivasi atau dorongan dalam diri peserta senam aerobik ini akan menjadi lebih aktif karena dipengaruhi oleh beberapa faktor dari luar diri individu tersebut, diantaranya ada perhatian dan dukungan dari pemuka masyarakat, dalam hal ini bapak Lurah Lubuk Buaya Kecamatan Koto Tangah Kota Padang, bapak RW IX berserta perangkatnya. Kemudian adanya keinginan dari dua orang warga Perumahan Pondok Pinang Lubuk Buaya Kecamatan Koto Tangah Kota Padang, yang kebetulan dosen di Fakultas Ilmu Keolahragaan Universitas Negeri Padang untuk mendukung kegiatan ini tetap dilaksanakan secara berkelanjutan.

Meningkatnya nilai dan sikap, serta hubungan antar warga masyarakat Perumahan Pondok Pinang Lubuk Buaya Kecamatan Koto Tangah Kota Padang yang mengikuti kegiatan senam aerobik. Hal ini dapat dilihat dari keterampilan gerak berirama yang ditunjukkan warga yang memiliki tingkat kemampuan gerakan yang berbeda-beda.

Kegiatan senam aerobik yang dilakukan secara bersama-sama di lapangan yang terletak ditengahtengah perumahan warga, yang diikuti dengan penuh semangat dan kegembiraan. Terjalin hubungan yang harmonis antar peserta senam aerobik, adanya kebersamaan untuk bersedia dan mau mengikuti kegiatan senam aerobik yang dilakukan pada setiap hari minggu jam 6.30. Hal ini menimbulkan perubahan sikap dan prilaku positif yang ditampilkan oleh para peserta senam aerobik, mapu menyesuaikan waktu, mengorbankan atau menunda kegiatan lain dan memahami serta mempunyai pikiran positif terhadap kegiatan senam aerobik yang mereka lakukan demi memelihara kesehatan dan meningkatkan kebugaran jasmani. Dari hasil koordinasi awal, tim pelaksanan menyiapkan materi pembinaan dan pelatihan dengan memperhatikan materi keterampilan sesuai dengan kebutuhan kegiatan senam aerobik. Selain menyiapkan materi, tim pelaksanan juga melakukan pembekalan kepada warga untuk mempermudah pelaksanaan pembinaan senam aerobik dengan melatih beberapa orang warga untuk memiliki keterampilan, sehingga nantinya hal ini dapat dijadikan sebagai instruktur senam aerobik dan tidak perlu lagi mendatangkan instruktur dari luar. Selanjutnya setelah kegiatan senam aerobik dilakukan, para peserta senam aerobik diberikan sarapan pagi dan air mineral yang disediakan oleh tim pembinaan senam aerobik. Hal ini membuat para peserta senam aerobik tambah bersemangat dan merasa senang, dan masyarakat berharap kegiatan ini berlangsung lebih lama.

\section{Meningkatnya Pengetahuan Masyarakat Tentang Kebugaran Jasmani}

Dari hasil pengabdian masyarakat Perumahan Pondok Pinang Lubuk Buaya Kecamatan Koto Tangah Padang Kota Padang, adanya peningkatan tentang pengetahuan warga, khusus para ibu-ibu terhadap kegiatan senam aerobik dalam upaya meningkatkan kebugaran jasmani. Kebugaran jasmani adalah kapasitas maksimal untuk menghirup, menyalurkan dan menggunakan oksigen (Sarkey, 2003:74). Artinya seseorang yang dapat menghirup, menyalurkan dan menggunakan oksigen dengan baik dapat dikatakan sebagai kebugaran jasmani. Memiliki kebugaran jasmani yang baik merupakan keinginan setiap orang, berbagai upaya dilakukan diantaranya dengan meluangkan waktu untuk berolahraga. Diantara olahraga yang dapat dilakukan yaitu dengan melakukan senam aerobik seperti yang telah dilakukan oleh masyarakat Perumahan Pondok Pinang Lubuk Buaya Kecamatan Koto Tangah Padang Kota Padang. Senam aerobik adalah olahraga kesehatan yang meliputi segala jenis latihan yang menggunakan oksigen dengan menggerakan otot-otot besar secara ritmis, dinamis, cukup lama tanpa berhenti, cukup intensif sehingga tercapainya perubahan yang mengguntungkan bagi tubuh.

Para ahli lain juga mengartikan senam aerobik sebagai aktivitas tubuh yang dilakukan untuk membakar lemak sambil memperbaiki kekencangan otot yang dipimpin oleh pelatih/instruktur berpengalaman secara bersama-sama dengan diiringi musik yang sesuai dengan irama/gerakan untuk anggota tubuh yang bergerak. Senam aerobik ini sangat banyak diminati oleh para ibu-ibu karena merupakan olahraga yang mudah dilakukan karena mengikuti gerak instruktur dan mengikuti irama lagu. Gerakan senam dapat digunakan sedemikian rupa sehingga otot badan atau tubuh ikut bergerak, 
kemudian dapat menambah motivasi dan menyenangkan karena diiringi musik yang dipilih sesuai dengan selera pesenam.

Saat ini banyak para ibu-ibu di masyarakat Perumahan Pondok Pinang Lubuk Buaya Kecamatan Koto Tangah Padang Kota Padang, telah aktif mengikuti senam aerobik meskipun kebanyak umur mereka sudah di atas 30 tahun. Aktifitas senam aerobik yang mereka ikuti memang sangat membantu dalam meningkatkan pengetahuannya dan kemampuan tentang pentingnya kebugaran jasmani. Keunggulan senam aerobik tergolong latihan yang baik diterapkan pada masyarakat, karena hampir seluruh otot-otot besar dalam tubuh dapat digerakan dan dilatih terutama lengan dan kaki, di samping itu otot perut menjadi kuat.

Pembinaan kesegaran jasmani merupakan bagian dari pembinaan kondisi fisik. Istilah kesegaran jasmani merupakan terjemahan dari physical fitness bearti kemampuan jasmani. Sutarman dalam Bafirman (2013:123) mengatakan kesegaran jasmani adalah "suatu aspek fisik dari kesegaran menyeluruh (total fitnes) yang memberikan kesanggupan kepada seseorang untuk menjalankan hidup yang produktif dan dapat menyesuaikan diri pada tiap-tiap pembebanan fisik (physical stress) yang layak". Selanjutnya kebugaran jasmani bila dipandang secara fisiologis maka kesegaran jasmani diartikan sebagai kemampuan tubuh melakukan penyesuaian terhadap pembebanan fisik yang diberikan (dari aktivitas yang dilakukan) tanpa kelelahan yang berlebihan.

Meningkatnya Pengalaman Keterampilan Gerak Berirama

Sesungguhnya kebutuhan yang hakiki dari manusia antara lain adalah gerak, gerak yang spesifik yang dilakukan secara sadar dan bertujuan. Gerak merupakan keniscayaan dan tergolong kebutuhan dasar, karena bergerak manusia mampu bertahan hidup dan melalui gerak itulah manusia beberapa tujuan seperti pertumbuhan fisik, perkembangan mental dan sosial. Zaman sekarang kehidupan modern yang dikuasai oleh otomatisasi yang mengambil alih penyelesaian tugas atau kerja membuat manusia malas bergerak. Beberapa gejala yang tampak derajat kebugaran jasmaninya menurun, kesehatan terganggu seperti penyakit jantung dan paru-paru, serta lain-lain sebagainya.

Secara alamiah manusia diciptakan sebagai makhluk yang dinamik, karena mempunyai kemampuan gerak yang sangat besar, karena strusktur tubuh manusia yang bertumpu pada dua belah kaki dan titik beratnya tergolong tinggi. Jelaslah bahwa manusia mempunyai potensi gerak yang lebih tinggi, bergerak secara luwes dan dapat menghindari atau mengatasi permasalahan yang dihadapi manusia dalam melakukan kegiatan sehari-hari. Di samping itu kekurangan gerak atau keterlibatan secara aktif dalam berolahraga menurut Lutan dkk (1991:36) “(1) dapat menyebabkan derajat kesegaran jasmani rendah, sehingga dalam kehidupan nyata orang akan lekas menderita kelelahan pada saat melakukan tugas sehari-hari. (2) Sistem otot dalam keadaan lemah yang menyebabkan kekuatan, kecepatan, dan daya tahan rendah. (3) Penampilan nampak loyo dan gairah hidup kurang.

Pengalaman gerak yang diberikan dalam pembinaan senam aerobik yang dilakukan masyarakat di Perumahan Pondok Pinang Lubuk Buaya Kecamatan Koto Tangah Kota Padang dapat meningkatkan keterampilan gerakan. Hal ini dapat dijadikan salah satu solusi dalam memilihara dan bahkan dapat meningkatkan kebugaran jasmani. Dengan demikian kekurangan gerak tidak akan terjadi apabila semua masyarakat mengerti dan memahami gerakan-gerakan yang dilakukan dalam kegiatan senam aerobik, membuat seseorang memperkaya gerak yang mereka miliki. Keterampilan gerakan yang disajikan pada peserta senam aerobik di Perumahan Pondok Pinang Lubuk Buaya Kecamatan Koto Tangah Kota Padang meliputi berbagai gerak dalam a (1) melakukan pemanasan (warming-up) selama 5-8 menit atau 10-15 menit. (2) Melakukan gerakan peregangan, karena dalam senam aerobik membutuhkan kelenturan yang baik dan dapat dicapai dengan latihan peregangan. (3) Melakukan latihan senam aerobik dengan mengikuti rangkaian gerakan yang diiringi dengan musik dan dipandu oleh instruktur.

Dengan demikian dapat dijelaskan bahwa dari berbagai gerakan disajikan dalam bentuk rangkai gerakan yang diiringi dengan musik, sudah ditata sedemikian rupa, dan yang pasti melibatkan aktifitas fisik dengan waktu relatif lama. Jenis musik yang dipakai untuk kegiatan senam aerobik adalah jenis musik pop dan dangdut yang sangat populer di Indonesia. Musik pop, biasanya alunan musik/refren yang mudah diingat dan mempunyai daya tarik bagi peserta senam aerobik. Sedangkan musik dangdut mempunyai ciri-ciri tempo musik yang dapat membikin orang untuk bergoyang atau lebih banyak bergerak. Gerakan pemanasan dimaksud dilakukan dengan gerak banyak ditempat, kemudian diutamakan gerakan yang bersifat kalistenik karena hal ini baik untuk meregangkan otot, dengan ketentuan gerak kalistenik sebagai tambahan. Kemudian gerakan peregangan ditampilan yang sifatnya untuk menggurangi ketegangan otot, membantu koordinasi gerakan tubuh, mencegah cidera atau kecelakaan dalam melakukan latihan senam aerobik, dapat membuat aktifitas latihan yang berat menjadi ringan, dan dapat memperlancar sirkulasi darah, serta membantu pengenduran saraf otak.

Keterampilan gerakan senam aerobik yang diberikan oleh instruktur sangat bervariasi dan dikembangkan dalam hal ; (1) Rangkaian gerakan tangan lebih dikembangkan dan bervariasi untuk 
mencapai intensitas latihan atau melatih otot-otot tertentu. Koreografikan rangkaian gerakan tangan dengan lebih kreaktif dapat diterapkan secara sistematis dan mendemontrasikan gerakan yang dilakukan oleh instruktur. (2) Pola ruang yang berpindah, maksudnya menggunakan pola yang lebih variaktif dengan pola bentuk berpindah ke depan, kesamping kanan dan ke samping kiri, mundur ke belakang dan berputar. Rangkaian gerakan latihan yang diberikan akan dapat meningkatkan pengayaan keterampilan gerakan secara bervariasi dengan berputar dengan empat arah yaitu muka, belakang, samping kanan dan samping kitri. Variasi yang dimaksud dalam hal ini adalah menggunakan gerakan yang mudah diserap oleh peserta senam aerobik dan mampu mengikuti variasi-variasi gerakan yang dilakukan oleh instruktur yang berada di depan para peserta senam aerobik di Perumahan Pondok Pinang Lubuk Buaya Kecamatan Koto Tangah Kota Padang.

Kemudian instruktur senam aerobik pada saat latihan juga memberikan keterampilan gerak variasi langkah kaki pada peserta latihan senam aerobik dengan berbagai gerakan seperti melakukan berjalan ke depan atau kebelakang, ke samping kiri dan ke samping kanan, serta berputar sambil menhentakhentakan kaki dengan irama musik yang mengairahkan sambil para peserta mengikuti dengan penuh semangat dengan mengikuti nyanyian. Hal ini dilakukan dengan tujuan agar peserta senam aerobik tidak merasa bosan untuk mengikuti gerakan-gerakan yang diterapkan instruktur. Selanjutnya peserta senam aerobik juga memperoleh keterampilan gerak dengan tujuan untuk penenangan, atau yang lebih dikenal dengan pendinginan (cooling down) selama 5-8 menit dan kadang-kadang dilakukan selama 10-15 menit. Pendingin ini dilakukan dengan gerakan yang bersifat kalistemik agar dapat menurunkan suhu tubuh kepada kondisi semula. Pendinginan (cooling down) dapat diartikan yaitu melakukan gerakan-gerakan ringan untuk beberapa saat setelah melakukan kegiatan latihan gerakan inti yang berat dan pendinginan bagian yang tidak boleh dilupakan dari latihan-latihan senam aerobik yang dilakukan. Dari hasil penelitian pendinginan (cooling down) sangat bermanfaat bagi otot, ligamen dan tendo, serta dapat menurunkan secara bertahap kecepatan denyut jantung menjadi seperti waktu istirahat.

Meningkatnya Motivasi Dan Antusias Masyarakat Terhadap Kegiatan Olahraga Senam Aerobik

Motivasi dapat diartikan dorongan atau semangat yang ada dalam diri seseorang untuk sukses dalam suatu pekerjaan. Motivasi ini disebut motivasi yang bersifat positif, seseorang yang memiliki motivasi yang tinggi dalam belajar atau berlatih suatu keterampilan tentu akan lebih cepat mendapatkan dan menguasai suatu keterampilan. Misalnya keterampilan gerakan dalam senam aerobik. Kemudian motivasi orang untuk melakukan senam aerobik dapat memenuhi tujuan, harapan dan kebutuhan akan sesuatu yang berguna bagi diri seseorang. Dalam hal ini tentu dikaitkan dengan tujuan untuk memelihara dan meningkatkan kebugaran jasmani.

Meningkatnya motivasi dan antusias masyarakat di Perumahan Pondok Pinang Lubuk Buaya Kecamatan Koto Tangah Kota Padang terhadap kegiatan senam aerobik. Hal ini dapat dilihat dari kehadiran para peserta senam aerobik di lapangan dan semangat dalam mengikuti serangkaian gerakan yang dipandu dengan irama dan mengikuti instruktur yang menyenangkan. Pengertian motivasi menurut Sudibyo Setyobroto (2001:24) adalah "proses aktualisasi sumber penggerak dan pendorong tingkah laku individu memenuhi kebutuhan untuk mencapai tujuan tertentu".

Masyarakat di Perumahan Pondok Pinang Lubuk Buaya Kecamatan Koto Tangah Kota Padang motivasinya terhadap senam aerobik meningkat, hal ini dapat dilihat dari kehadiran, semangat, ketekunan dan konsentrasi para peserta senam aerobik dalam mengikuti setiap gerakan senam aerobik yang diberikan instruktur dengan berbagai-bagai variasi latihan mulai dari awal pemanasan, latihan inti dan latihan pendinginan atau sampai berakhirnya latihan. Motivasi merupakan dorong yang muncul dalam diri individu untuk melakukan sesuatu kegiatan dengan tujuan tertentu. Motivasi atau dorongan dalam diri peserta senam aerobik ini akan menjadi lebih aktif karena dipengaruhi oleh beberapa faktor dari luar diri individu tersebut, diantaranya ada perhatian dan dukungan dari pemuka masyarakat, dalam hal ini bapak Lurah Lubuk Buaya Kecamatan Koto Tangah Kota Padang, bapak RW IX berserta perangkatnya. Kemudian adanya keinginan dari dua orang warga Perumahan Pondok Pinang Lubuk Buaya Kecamatan Koto Tangah Kota Padang, yang kebetulan dosen di Fakultas Ilmu Keolahragaan Universitas Negeri Padang untuk mendukung kegiatan ini tetap dilaksanakan secara berkelanjutan.

Meningkatnya Nilai dan Sikap Positif Masyarakat Terhadap Olahraga Senam Aerobik

Dengan melakukan olahraga senam aerobik yang diikuti secara teratur dan dengan aturan yang benar, dapat meningkatkan nilai dan sikap positif yang meningkat dari para pengikut senam aerobik tersebut Diantara meningkatnya rasa disiplin dan tanggung jawab, rasa percaya diri, penguasaan diri yang erat hubungannya dengan kematangan emosional, serta munculnya motif untuk berprestasi sebagai instruktur senam aerobik. Menurut Sudibyo Setyobroto (2001:73) disiplin dan tanggung jawab adalah sikap atau kesediaan psikologik untuk menepati atau mendukung nilai-nilai atau norma yang berlaku. Hal ini bila dikaitkan dengan disiplin dan tanggung jawab mayarakat Perumahan Pondok Pinang terhadap 
kegiatan senam aerobik, terlihat dari kehadiran tepat waktu, dan mau melakukan kegiatan sesuai dengan yang diberikan.

Kemudian meningkatkan rasa percaya diri dalam melakukan gerakan-gerakan yang diberikan pelatih/instruktur senam aerobik, meskipun mereka memiliki beberapa keterbatasan, seperti waktu dan pengalaman gerak yang dimiliki. Kepercayaan diri sangat penting dalam pembinaan senam aerobik, karena percaya diri sendiri biasanya akan menimbulkan rasa aman, dalam melakukan dia merasa tenang, tegas dan emosionalnya stabil. Selanjutnya kepercayaan diri juga sangat bermanfaat dalam mencapai kesuksesan, misalnya sukses dalam mempelajari dan menguasai keterampilan gerak yang dalam senam aerobik.

Meningkatnya nilai dan sikap, serta hubungan antar warga masyarakat Perumahan Pondok Pinang Lubuk Buaya Kecamatan Koto Tangah Kota Padang yang mengikuti kegiatan senam aerobik. Hal ini dapat dilihat dari keterampilan gerak berirama yang ditunjukkan warga yang memiliki tingkat kemampuan gerakan yang berbeda-beda. Namun mereka tetap menampilkan sikap kebersamaan bahwa mereka samasama belajar. Memang setiap manusia ingin memenuhi kebutuhan dan mendapat kepuasan dengan memahami dan menyadari harus adanya kemauan yang kuat dan kerja keras dalam melakukan latihan senam aerobik. Kegiatan senam aerobik yang dilakukan secara bersama-sama di lapangan yang terletak ditengah-tengah perumahan warga, yang diikuti dengan penuh semangat dan kegembiraan. Terjalin hubungan yang harmonis antar peserta senam aerobik, adanya kebersamaan untuk bersedia dan mau mengikuti kegiatan senam aerobik yang dilakukan pada setiap hari minggu jam 6.30. Hal ini menimbulkan perubahan sikap dan prilaku positif yang ditampilkan oleh para peserta senam aerobik, mapu menyesuaikan waktu, mengorbankan atau menunda kegiatan lain dan memahami serta mempunyai pikiran positif terhadap kegiatan senam aerobik yang mereka lakukan demi memelihara kesehatan dan meningkatkan kebugaran jasmani.

\section{Simpulan dan saran}

Program penerapan Ipteks kepada masyarakat sudah dilakukan berupa pembinaan senam aerobik dalam upaya meningkatan kebugaran jasmani masyarakat Pondok Pinang Lubuk Buaya Kecamatan Koto Tangah Kota Padang. Pembinaan ini diawali dengan penjelasan tentang kebugaran jasmani adalah merupakan kondisi individu dari kebugaran menyeluruh (total fittness) yang memberikan kesanggupan kepada seseorang untuk menjalankan hidup yang produktif dan dapat menyesuaikan pada tiap pembebanan atau stress fisik yang layak.

Kemudian diberikan pengetahuan penekan bahwa kegiatan senam aerobik yang dilakukan secara teratus dan sesuai dengan takaran yang cukup dapat banyak membawa manfaat dalam menghadapi dan menjalankan kegiatan sehari-hari tanpa mengalami kelelahan yang berarti dan diberikan beberapa keterampilan awal gerak senam aerobik, dan kemudian dilanjutkan dengan pelatihan bagi ibu-ibu yang bersedia dilatih sebagai instruktur earobik. Dari hasil pembinaan dan pelatihan rangkaian gerakan senam aerobik mulai dari awal koordinasi dan selama pelaksanaan pengabdian, masyarakat sangat mengharapkan pembinaan senam aerobik dilakukan dengan waktu yang lebih lama.

Namun kegiatan ini diharapkan tidak berakhir pada kegiatan pengabdian, tetapi bisa dibentuk kerjasama dalam penyebaran informasi tentang pentingnya dan manfaat dari kegiatan senam aerobik dalam upaya meningkatkan kesehatan dan kebugaran jasmani. Selanjutnya kegiatan ini akan tetap dilanjutkan karena mendapat dukungan dari masyarakat, khususnya dari ibu-ibu Perumahan Pondok Pinang Lubuk Buaya Kecamatan Koto Tangah Kota Padang dan sudah mendapat kesepakatan bersama untuk melakukan kegiatan senam aerobik ini untuk seterusnya dilakukan dengan instruktur yang dibina dan dilatih selama pengabdian masyarakat yang dilakukan oleh pengabdi program penerapan pteks bagi Masyarakat Universitas Negeri Padang

\section{Daftar Rujukan}

Astuti, Yuni dan Mardius Ali. (2017). Pelatihan Massage Di Komplek Perumahan Adinegoro Indah Kelurahan Batang Kabung, Kecamatan Koto Tangah, Kota Padang. Jurnal Pengabdian Kepada Masyarakat LPPM Universitas Islam Nusantara, volume 7 No. 2 (108-113).

Azmy Andini, Eka Novita Indra. 2016. Perbedaan Pengaruh Frekuensi Latihan Senam Aerobik Terhadap Penurunan Persentase Lemak Tubuh Dan berat Badan Pada Members Wanita. jurnal Medikora UNY. VOL. VX No. 1 April.

Bafirman. (2013). Fisiologi Olahraga. Malang: Wineka Media. 
Depdiknas, (2000). Pedoman dan Modul Pelatihan Kesehatan Olahraga Bagi Pelatih Olahragawan Pelajar.

Erianti, (2011). Buku Ajar Bola Voli. Padang: FIK UNP Padang.

Erianti. (2011). Buku Ajar Bolavoli. Padang: Sukabina Press.

Fathirina Sientia, Niken Puruhita. 2012. Pengaruh Latihan Senam Aerobik Terhadap Perubahan Berat Badan Pada Peserta Klub Kebugaran. Jurnal Kedokteran Diponegoro. Vol 1, No 1.

Ismaryati. (2008). Tes Dan Pengukuran Olahraga. Surakarta: UNS Pres.

Jeane Betty, K J. 2013. Pengaruh Senam Aerobik Terhadap Tingkat Kebugaran Jasmani Siswa Putri Kelas Vii Smp Kartika X11-1 Mertoyudan Magelang. jurnal Medikora UNY. VOL. VX No. 1 April.

Mardius, Ali dan Astuti Yuni. (2017). Pengaruh Senam Lansia Terhadap Kebugaran Jasmani Warga Perumahan Pondok Pinang Kelurahan Lubuk Buaya Kecamatan Koto Tangah Kota Padang. Journal of Education Research and Evaluation. Vol.1 (3) pp. 147-152

Mutohir Toho Cholik. (2004). Perkembangan Motorik Pada Masa Anak-Anak. Jakarta: Dirjen Olahraga Depdiknas.

Nanik Sugiarti, Zulkhah Noor. 2009. Pengaruh Program Olahraga Umum (Senam Aerobik) dan Khusus (Body Language dan Senam Aerobik) terhadap Penurunan Berat Badan. Jurnal Kedoteran dan Kesehatan UMY. Vol. 8, No. 1.

Nugraheni Sriwahyu Ningsih. (2013). Faktor-Faktor Yang Berhubungan Dengan Tingkat Kebugaran Jasmani Pada Lansia di Panti Wreda Dharma Bhakti. Surakarta: Jurnal Infokes. 3 (1) : 34.

Pitnawati. (2013). Senam Aerobic. Padang: Fakultas Ilmu Keolahragaan Universitas Bung Hatta.

Prijo Sudibjo, Djoko Prakosa dkk. 2013. Pengaruh Senam Aerobik Intensitas Sedang Dan Intensitas Tinggi Terhadap Persentase Lemak Badan Dan Lean Body Weight. Kajian Anthropometris UNY. Vol 3, No 1.

Purwanto. 2011. Dampak Senam Aerobik terhadap Daya Tahan Tubuh dan Penyakit. Jurnal Media Ilmu Keolahragaan Indonesia. Vol 1, No 1. Edisi Juli.

Rosmalina Yuniar, dkk. 2003. Faktor-Faktor Yang Berhubungan Dengan Tingkat Kesegaran Jasmani Lansia Laki-Laki Tidak Anemia. Jakarta: Jurnal PGM. 26 (1) : 11.

Sharkey Brian J. (2003). Kebugaran \& Kesehatan. Jakarta: PT Raja Grafindo Persada.

Syafruddin. (2011). Dasar- Dasar Kepelatihan Olahraga. Padang: Fakultas Ilmu Keolahragaan, Universitas Negeri Padang. 